\title{
SKRINING FITOKIMIA, ANTIOKSIDAN DAN AKTIVITAS ANTIBAKTERI EKSTRAK ETANOL AKAR SEGAR BANGLE (Zingiber montanum)
}

\section{PHYTOCHEMICAL SCREENING, ANTIOXIDANT AND ANTIBACTERIAL ACTIVITY OF ETHANOL EXTRACT OF BANGLE FRESH ROOT (Zingiber montanum)}

\author{
Amalia Riska Setyani ${ }^{1}$, Enos Tangke Arung ${ }^{2,3}$, dan Yanti Puspita Sari ${ }^{1 *}$ \\ ${ }^{1}$ Jurusan Biologi, Fakultas Matematika dan Ilmu Pengetahuan Alam, \\ Universitas Mulawarman, Samarinda \\ ${ }^{2}$ Fakultas Kehutanan, Universitas Mulawarman, Samarinda \\ ${ }^{3}$ Research Center for Drugs and Cosmetics from Tropical Rainforest Resources \\ (PUI OKTAL), Universitas Mulawarman, Samarinda \\ *e-mail: ypsman2002@yahoo.com
}

Diterima: 01-11-2021

Direvisi: 04-12-2021

Disetujui: 15-12-2021

\begin{abstract}
ABSTRAK
Bangle (Zingiber montanum) merupakan family zingiberaceae yang dimanfaatkan sebagai obat tradisional untuk mengobati beberapa penyakit. Tanaman bangle yang dikembangkan sebagai obat tradisonal tidak lepas dari kandungan senyawa aktif didalamnya. Kandungan senyawa aktif tanaman bangle memiliki efek aktivitas antioksidan dan antibakteri. Tujuan penelitian ini yaitu untuk mengetahui senyawa fitokimia, aktivitas antioksidan dan konsentrasi efektif ekstrak akar segar bangle (Z. montanum) dalam menghambat pertumbuhan bakteri Escerichia coli dan Streptococcus sobrinus. Penelitian ini menggunakan metode kolorimetri, DPPH dan kertas cakram (tes Kirby \& Baurer). Sampel yang digunakan ekstrak etanol akar segar bangle dengan konsentrasi ekstrak $25 \%, 50 \%, 75 \%$, $100 \%$. Kontrol positif yaitu kloromfenicol dan kontrol negatif yaitu etanol $10 \%$. Hasil penelitian menunjukkan bahwa ekstrak akar segar mengandung senyawa fitokimia berupa alkaloid, fenolik, flavonoid, saponin dan triterpenoid serta nilai TPC, TFC, dan antioksidan adalah $49.01 \mathrm{mg} \mathrm{GAE} / \mathrm{g}$, $394.07 \mathrm{mg} \mathrm{CE} / \mathrm{g}$ dan $0.993 \mu \mathrm{g} / \mathrm{mL}$. Aktivitas antibakteri memiliki daya hambat pada bakteri Escherichia coli dan Streptococcus sobrinus dengan konsentrasi 100\% secara berturut-turut adalah $16.18 \mathrm{~mm}$ dan $9.86 \mathrm{~mm}$.
\end{abstract}

Kata Kunci: akar segar bangle, aktivitas antioksidan, antibakteri, uji fitokimia

\section{ABSTRACT}

Bangle (Zingiber montanum) is the Zingiberaceae family used as a traditional medicine to treat some diseases. The Bangle plant developed as traditional medicine cannot be separated from the active compounds. The active compound content of the bangle plant has the effect of antioxidant and antibacterial activity. This study aimed to determine the phytochemical compounds, antioxidant activity, and effective concentration of bangle fresh root extract (Z. montanum). This was to inhibit the growth of Escherichia coli and Streptococcus sobrinus bacteria. This research used the colorimetric method, DPPH, and disc paper (Kirby \& Baurer test). The sample used ethanol extract of fresh bangle root with extract concentrations of $25 \%, 50 \%, 75 \%, 100 \%$. The positive control was chloramphenicol, and the negative control was $10 \%$ ethanol. The results showed that the fresh root extract contained phytochemical compounds in the form of alkaloids, phenolics, flavonoids, saponins, and triterpenoids. The TPC, TFC, and antioxidant values were $49.01 \mathrm{mg} \mathrm{GAE} / \mathrm{g}, 394.07 \mathrm{mg} \mathrm{CE} / \mathrm{g}$, and $0.993 \mu \mathrm{g} / \mathrm{mL}$. Antibacterial activity had inhibitory activity in Escherichia coli and Streptococcus sobrinus bacteria with a concentration of $100 \%$, respectively $16.18 \mathrm{~mm}$ and $9.86 \mathrm{~mm}$.

Keywords: bangle fresh root, antioxidant activity, antibacterial, phytochemical screening 


\section{PENDAHULUAN}

7 anaman bangle (Zingiber montanum) termasuk ke dalam family Zingiberaceae yang merupakan tanaman herba tropis atau subtropics yang dapat tumbuh di Indonesia. Tanaman bangle dapat dijadikan sebagai obat tradisional untuk menyembuhkan berbagai penyakit. Bagian tanaman bangle yang biasa digunakan sebagai pengobatan tradisional adalah rimpang. Rimpang bangle memiliki banyak khasiat sebagai obat demam, sembelit, cacingan, nyeri perut, masuk angin dan encok (Batubara et al., 2018). Selain itu, rimpang bangle juga mempunyai aktivitas antioksidan dan imunomodulator untuk meningkatkan aktivitas fagositosis secara in vitro. Rimpang bangle memiliki komponen utama berupa minyak atsiri yang didalamnya terdapat kandungan senyawa kimia seperti pinen, karyofillen, sabinene dan caryofillen oxide (Nurkhasanah et al., 2017).

Potensi dari rimpang tanaman bangle yang dapat dijadikan sebagai pengobatan tidak lepas dari kandungan senyawa aktif didalamnya seperti ekstrak etanol rimpang yang mengandung kurkumin sebesar $0,0175 \mathrm{~g} / 100 \mathrm{~g}$. Senyawa fitokimia dari ekstrak $C$. aromatic dapat berupa saponin, flavonoid, tanin, terpenoid dan sterol (Rungruang et al., 2021). Senyawa metabolit sekunder yang melimpah pada tanaman dapat dijadikan sebagai sumber baru dengan berbagai komponen kimia untuk dikembangkan sebagai obat tradisional (Aunjum et al., 2019). Tanaman obat dewasa ini banyak digunakan untuk mengobati berbagai penyakit infeksi yang dipengaruhi oleh beberapa faktor seperti infeksi mikroba dan keadaan lingkungan yang sesuai untuk perkembangan mikroba.

Escherichia coli merupakan bakteri gram negatif yang bersifat fakultatif anaerobik, bersifat motil dengan memiliki flagela petritikus, tidak membentuk spora dan mampu bertahan hidup dalam media yang miskin nutrisi. Karakteristik biokimia $E$. coli yaitu bersifat negatif pada analisis urease, memiliki kemampuan dalam memproduksi indol dan tidak mampu dalam memfermentasikan sitrat. Bakteri E.coli juga termasuk ke dalam flora normal yang dapat menyebabkan penyakit pada manusia yaitu hemolytic uremic syndrome (HUS), keracunan makanan, diare dan hemorrhagic colitis (HC) (Rahayu, 2018) (Prasetya et al., 2019).

Infeksi lain yang ditemukan pada manusia adalah infeksi dari bakteri kariogenik penyebab utama karies gigi. Mikroorganisme yang menyebabkan terjadinya karies gigi yang sering ditemukan di dalam rongga mulut manusia salah satunya adalah bakteri Streptococcus sobrinus. Bakteri $S$. sobrinus memiliki kemampuan untuk hidup pada lingkungan yang asam dan bersifat anaerobik. Selain itu, bakteri tersebut dapat menghasilkan asam laktat dan memiliki kemampuan bakteri yang menempel dengan kuat sehingga tidak mudah lepas pada permukaan gigi (Egra et al., 2019).

Beberapa hasil penelitian menunjukkan bahwa senyawa metabolit sekunder yang dimiliki tanaman dapat bersifat antibakteri. Senyawa yang terdapat dalam ekstrak rimpang $Z$. zerumbet dari Pulau Timor memiliki aktivitas antibakteri karena memiliki kandungan gingerglikolipid $B$ dan zerumbon yang mampu menghambat pertumbuhan bakteri $S$. aureus, E. coli, P. aeruginosa dan B. subtilis (Kapitan et al., 2017). Kandungan metabolit sekunder dari tanaman Hornstedtia scyphifera var. Fusiformis Holttum yang merupakan salah satu famili Zingiberaceae mampu menghambat pertumbuhan bakteri terhadap $E$. coli dan S. aureus (Santoni, 2019).

Berdasarkan latar belakang di atas, dan belum ada penelitian tentang kandungan metabolit sekunder akar tanaman bangle yang diambil dari alam dan uji antibakterinya, maka dilakukan penelitian ini untuk mengetahui kandungan metabolit sekunder yang dimiliki oleh akar bangle serta mengetahui konsentrasi terbaik dari ekstrak akar tersebut dalam menghambat pertumbuhan bakteri.

Tujuan dari penelitian ini yaitu untuk mengetahui senyawa fitokimia, aktivitas antioksidan dan konsentrasi efektif ekstrak akar bangle (Zingiber montanum) dalam 
menghambat pertumbuhan bakteri Escerichia coli dan Streptococcus sobrinus. Manfaat dari penelitian ini diharapkan dapat memberikan informasi mengenai potensi dari kandungan senyawa metabolit sekunder, antioksidan dan antibakteri dari ekstrak akar bangle ( $Z$. montanum).

\section{BAHAN DAN METODA Bahan Dan Alat}

Bahan-bahan yang digunakan adalah akar bangle segar (Zingiber montanum) yang diperoleh dari Fahutan Unmul Samarinda, vaselin, es batu, kertas saring, kertas label, aquades, ekstrak akar bangle ( $Z$. montanum), etanol $95 \%$, etanol $96 \%$, etanol $70 \%$, HCL pekat (merck), larutan dragendroff, $\mathrm{NaOH} 1 \mathrm{M}$ (merck), larutan $\mathrm{FeCl} 1 \%$ (merck), serbuk $\mathrm{Mg}$ (merck), aquadest, asam asetat anhidrat (merck), $\mathrm{H}_{2} \mathrm{SO}_{4}$ pekat (merck), dimethyl sulfoxide (merck), asam galat (merck), $\mathrm{NaCO}_{3} 20 \%$ (merck), folin ciocalteu (merck), catechin (merck), $\mathrm{NaNO}_{2} 5 \%$ (merck), $\mathrm{AlCl}_{2}$ 10\% (merck), DPPH (sigma), Vitamin C, media NA (Merck), media NB (Merck), glucose (merck), biakkan bakteri Escherichia coli, Streptococcus sobrinus, kloramfenikol, etanol $10 \%$, kapas, aluminium foil, tisu, wrapping dan kertas cakram.

Alat-alat yang digunakan antara lain adalah neraca analitik (Mettler Teledo made in Switzerldan), botol sampel, rotary evaporator (Buchi made in Switzerldan), gelas ukur, vacuum pump, corong kaca, blender, spatula, tabung reaksi, labu ukur, hot plate, beaker glass, sprektofotometer, mikropipet, blue tipe, yellow tipe, gelas ukur, lumpang, alu, cawan petri, Erlenmeyer, jarum ose, autoclave (Tomy SX500 UD), jangka sorong, laminar air flow cabinet (ESCO), lampu Bunsen dan magnetic stirrer.

\section{Metode}

Penelitian ini dilakukan di Laboratorium Fisiologi dan Perkembangan Hewan Fakultas Matematika dan Ilmu Pengetahuan Alam dan Laboratorium Sifat-sifat Kayu dan Analisis Produk, Politeknik Pertanian Negeri Samarinda, Kalimantan Timur. Penelitian ini menggunakan metode deskriptif untuk analisis jenis metabolit sekunder yang terkandung di dalam akar bangle, analisis nilai TPC (Total Phenolic Content) dan TFC (Total Flavonoid Content) dengan menggunakan metode kolorimetri, aktivitas antioksidan menggunakan metode DPPH. Pengujian aktivitas antibakteri menggunakan metode kertas cakram (tes Kirby \& Baurer) yang setiap perlakuan diulang sebanyak 4 kali dengan ekstrak akar segar tanaman bangle ( $Z$. montanum) dalam konsentrasi yang terdiri dari $25 \%, 50 \%, 75 \%, 100 \%$ dan dua kelompok kontrol, yaitu kontrol positif (kloromfenicol) dan kontrol negatif (etanol 10\%) (Citradewi et al., 2019).

\section{Pembuatan Ekstrak Akar Bangle}

Akar bangle ( $Z$. montanum) dipilih yang masih segar, dicuci bersih, dipotong-potong dan kemudian akar diblender. Hasil yang didapatkan berbentuk serbuk kasar berwarna putih kekuningan. Serbuk akar segar bangle (Z. montanum) sebanyak 417 gram dimaserasi dengan $800 \mathrm{~mL}$ pelarut etanol $96 \%$ selama 3 hari sampai warnanya bening. Hasil maserat yang diperoleh diuapkan dengan rotary evaporator pada suhu $40-50^{\circ} \mathrm{C}$ dan maserat dipanaskan di atas penangas air pada suhu $\pm 50^{\circ} \mathrm{C}$ hingga didapatkan ekstrak kental yang akan digunakan untuk uji fitokimia, antioksidan dan uji antimikroba (Riasari et al., 2019).

Menurut Wijaya et al. (2018) hasil rendemen ekstrak tanaman dapat dihitung dengan menggunakan rumus sebagai berikut:

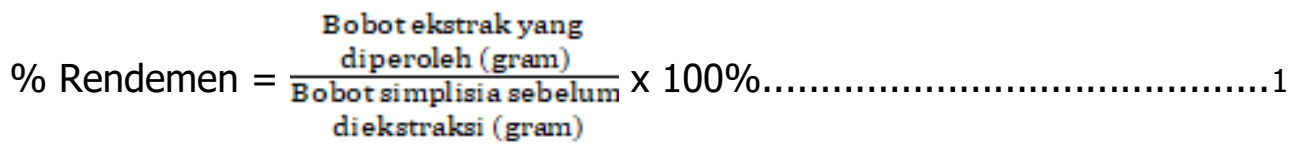




\section{Analisis kualitatif}

a. Uji Alkaloid (Uji dragendroff)

Ekstrak akar bangle ditimbang sebanyak $0,10 \mathrm{~g}$ lalu dimasukkan ke dalam tabung reaksi, ditambahkan 3 tetes larutan Dragendorf (campuran $\mathrm{Bi}\left(\mathrm{NO}_{3}\right)_{2.5} \mathrm{H}_{2} \mathrm{O}$ dalam asam nitrat dan larutan KI). Terbentuknya endapan warna merah coklat menandakan bahwa larutan ekstrak akar bangle positif mengandung alkaloid (Wachidah, 2013).

b. Uji Flavonoid

Ekstrak akar bangle ditimbang sebanyak $0,10 \mathrm{~g}$ lalu dimasukkan ke dalam tabung reaksi, ditambahkan 0,05 mg serbuk $\mathrm{Mg}$ dan $1 \mathrm{~mL} \mathrm{HCL}$ pekat lalu dikocok hingga homogen. Warna merah, hijau kekuningan atau jingga yang terbentuk menandakan ekstrak akar bangle positif mengandung flavonoid (Wachidah, 2013).

c. Uji Fenolik

Ekstrak akar bangle ditimbang sebanyak $0,10 \mathrm{~g}$ lalu dimasukkan ke dalam tabung reaksi, ditambahkan $\mathrm{FeCl}_{3} 1 \%$ sebanyak 3 tetes dan dihomogenkan. Warna hijau, merah, ungu, biru atau hitam pekat yang terbentuk menandakan bahwa larutan ekstrak akar bangle positif mengandung fenolik (Wachidah, 2013).

d. Uji Saponin/ Uji Froth

Ekstrak akar bangle ditimbang sebanyak $0,10 \mathrm{~g}$ lalu dimasukkan ke dalam tabung reaksi, ditambahkan $5 \mathrm{~mL}$ air panas lalu dikocok kuat-kuat selama \pm 10 detik. Apabila terbentuk busa pada larutan ekstrak yang diuji selama \pm 10 menit dan jika ditambahkan 1 tetes $\mathrm{HCL} 2 \mathrm{~N}$ busa tersebut tidak hilang menandakan ekstrak akar bangle positif mengandung saponin (Wachidah, 2013).

e. Uji Steroid-Triterpenoid

Ekstrak akar bangle ditimbang sebanyak $0,10 \mathrm{~g}$ ditambahkan 10 tetes $\mathrm{CH}_{3} \mathrm{COOH}$ glasial dan $\mathrm{H}_{2} \mathrm{SO}_{4}$ pekat sebanyak 2 tetes. Dikocok secara perlahan dan dibiarkan selama beberapa menit. Warna merah atau ungu menandakan ekstrak akar bangle positif mengandung triterpenoid dan warna biru atau hijau menandakan ekstrak akar bangle positif mengandung steroid (Febrina et al., 2015).

\section{Analisis kuantitatif}

\section{A. Nilai Total Phenolic Content (TPC) Persiapan Sampel}

Sampel ditimbang sebanyak 0,005 g untuk uji TPC dan TFC, dimasukkan sampel ke dalam tabung reaksi. Kemudian $1 \mathrm{~mL}$ DMSO (Dimethyl Sulfoxide) ditambahkan kedalam sampel dan dihomogenkan.

\section{Pembuatan Reagen \\ Pembuatan larutan induk asam galat (5 mg mL-1)}

Asam galat sebanyak 0,25 g dimasukkan ke dalam beaker glass, ditambahkan $5 \mathrm{ml}$ etanol 95\% lalu dihomogenkan. Larutan tersebut dipindahkan ke dalam labu ukur dan ditambahkan aquadest sampai mencukupi $50 \mathrm{~mL}$, kemudian dimasukkan ke dalam botol dan diberi label (Alfian \& Susanti, 2012).

\section{Pembuatan $\mathrm{Na}_{2} \mathrm{CO}_{3} 20 \%$}

$\mathrm{Na}_{2} \mathrm{CO}_{3}$ sebanyak $5 \mathrm{~g}$ dimasukkan ke dalam beaker glass, ditambahkan $20 \mathrm{~mL}$ aquadest yang telah dididihkan sebelumnya, lalu dihomogenkan. Setelah itu dipindahkan ke dalam botol dan diberi label. Didiamkan selama 24 jam, kemudian disaring dan diencerkan menggunakan aquadest sampai mencukupi $25 \mathrm{~mL}$ (Alfian \& Susanti, 2012). 


\section{Pembuatan Kurva Kalibrasi Asam Galat dan Penentuan Total Phenolic Content (TPC)}

Larutan induk asam galat $5 \mathrm{mg} \mathrm{mL}^{-1}$ dipipet sebanyak $0,1,0,2,0,3,0,4$ dan 0,5 dimasukkan kedalam tabung reaksi. Kemudian aquadest ditambahkan hingga mencapai $5 \mathrm{~mL}$ pada masing-masing tabung reaksi sehingga dihasilkan konsentrasi 100, 200, 300, 400 dan $500 \mathrm{mg} \mathrm{L}^{-1}$ asam galat.

Sampel dan masing-masing konsentrasi larutan asam galat dipipet sebanyak $40 \mu \mathrm{L}$ dengan 3 kali ulangan, lalu dimasukkan kedalam tabung reaksi, kemudian ditambahkan $3,160 \mu \mathrm{L}$ aquadest dan $200 \mu \mathrm{L}$ reagen Folin Ciocalteu kemudian dikocok hingga homogen. Didiamkan selama 8 menit, lalu ditambahkan $600 \mu \mathrm{L}$ larutan $\mathrm{Na}_{2} \mathrm{CO}_{3}$ kemudian dihomogenkan. Didiamkan selama 2 jam pada suhu kamar. Setelah itu diukur serapan panjang gelombang maksimum menggunakan Sprektrofometer UV-vis, lalu dibuat kurva kalibrasi hubungan antara konsentrasi asam galat $\left(\mathrm{mg} \mathrm{L}^{-1}\right)$ dengan absorbansi dengan hasil yang didapat (Alfian \& Susanti, 2012). Nilai TPC dapat dihitung dengan rumus:

Keterangan :

$$
\text { Nilai TPC }=\frac{\mathrm{CxV}}{\mathrm{M}}
$$

Nilai TPC $=$ ( $m g$ GAE/g crude extract $)$

C = konsentrasi hasil perhitungan kalibrasi ( $\mathrm{mg} / \mathrm{L})$

$V \quad=$ volume larutan ekstrak $(\mathrm{mL})$

M = massa ekstrak yang digunakan dalam analisa (g)

\section{B. Nilai Total Flavonoid Content (TFC)}

\section{Pembuatan Larutan Induk Cathechin}

0,0010 g katekin dimasukkan ke dalam beaker glass, lalu ditambahkan 1 mletanol 95\% dan dihomogenkan. Setelah itu dimasukkan ke dalam botol dan diberi label.

\section{Pembuatan Kurva Kalibrasi TFC}

Larutan induk katekin $200 \mathrm{mg} \mathrm{L} \mathrm{L}^{-1}$ dipipet sebanyak $0,1,0,5,0,25$ dan $1 \mathrm{~mL}$, dimasukkan kedalam tabung reaksi. Kemudian aquadest ditambahkan hingga mencapai $2 \mathrm{~mL}$ pada masing-masing tabung reaksi.

Ekstrak akar segar dan masing-masing konsentrasi larutan induk katekin dipipet sebanyak $250 \mu \mathrm{L}$ dengan 3 kali ulangan, lalu dimasukkan kedalam tabung reaksi. Ditambahkan aquadest sebanyak $1.250 \mathrm{ml}$, lalu ditambahkan $75 \mu \mathrm{L} \mathrm{NaNO}_{2} \quad 5 \%$ dan diinkubasi 5 menit. Ditambahkan $150 \mu \mathrm{L} \mathrm{AlCl}_{3} \quad 10 \%$ lalu diinkubasi lagi selama 5 menit. Ditambahkan $500 \mu \mathrm{L} \mathrm{NaOH} 1 \mathrm{M}$ dan $275 \mu \mathrm{L}$ aquadest. Diukur serapan panjang gelombang maksimum menggunakan Sprektrofometer UV-vis, lalu dibuat kurva kalibrasi hubungan antara konsentrasi katekin ( $\mathrm{mg} \mathrm{L}^{-1}$ ) dengan absorbansi pada hasil yang didapat (Zou et al., 2004). Nilai TFC dapat dihitung dengan rumus:

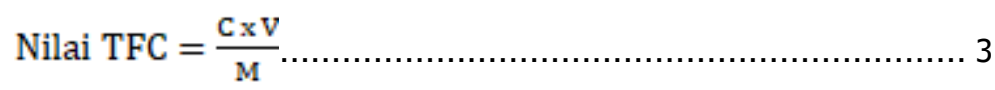

Keterangan :

Nilai $T F C=(m g C E / g$ crude extract $)$

$C \quad=$ konsentrasi hasil perhitungan kalibrasi ( $\mathrm{mg} / \mathrm{L})$

$V \quad=$ volume larutan ekstrak (L)

$M \quad=$ massa ekstrak yang digunakan dalam analisa $(g)$ 


\section{Uji Aktivitas Antioksidan}

Pembuatan larutan DPPH dengan menimbang Kristal DPPH sebanyak 2,4 mg dan dilarutkan dengan $100 \mathrm{~mL}$ etanol 70\%, lalu dihomogenkan. Kemudian ditempatkan dalam labu ukur yang gelap sehingga didapatkan larutan DPPH dengan konsentrasi $0,024 \mathrm{mg} / \mathrm{mL}$ yang digunakan pada pengujian. Larutan disimpan pada tempat yang terlindung dari cahaya dan tertutup rapat (Maizura, 2011).

Metode uji antioksidan yang akan digunakan pada penelitian ini berdasarkan metode (Arung et al., 2006), Uji yang dilakukan menggunakan spektrofotometer pada temperatur ruang $\left(25^{\circ} \mathrm{C}\right)$ dengan panjang gelombang $514 \mathrm{~nm}$ dan menggunakan larutan DPPH $(1,1$ diphenyl-2-picrylhydrazy).

Ekstrak sampel ditimbang $3 \mathrm{mg}$ dilarutkan dalam $1000 \mu \mathrm{l}$ DMSO sebagai stok larutan sampel dalam konsentrasi $3000 \mu \mathrm{g} / \mathrm{ml}$ untuk pengujian konsentrasi $100 \mathrm{ppm}$. Sampel yang telah dilarutkan kedalam DMSO di ambil $500 \mu \mathrm{L}$ dan ditambahkan $500 \mu \mathrm{L}$ DMSO untuk pengujian konsentrasi $1500 \mathrm{ppm}$.

Sampel yang telah dilarutkan kedalam DMSO di ambil $500 \mu \mathrm{L}$ dan ditambahkan 500 $\mu \mathrm{L}$ DMSO untuk pengujian konsentrasi 750 ppm, 375 ppm, 187,5 ppm, 93,75 ppm, 46,875 ppm dan 23,4375 ppm. Sampel stok dengan konsetrasi 3000 ppm, 1500 ppm, 750 ppm, 375 ppm, 187,5 ppm 93,75 ppm, 46,875 ppm dan 23,4375 ppm diambil $33 \mu \mathrm{L}$, ditambahkan $467 \mu \mathrm{L}$ etanol $70 \%$ dan larutan $500 \mu \mathrm{L}$ larutan DPPH yang dimasukan dalam cuvette sehingga konsentrasi akhirnya menjadi 100 ppm, 50 ppm, 25 ppm, 12,5 ppm, 6,25 ppm $3,125 \mathrm{ppm}, 1,5625 \mathrm{ppm}$ dan 0,78125 ppm. Pencampuran dicukupkan apabila volume sampel telah mencapai $1000 \mu$ l. Sampel diinkubasi selama 30 menit dalam ruang yang minim cahaya dan pada suhu ruangan. Aktivitas antioksidan ditentukan melalui dekolorisasi dari DPPH pada panjang gelombang $514 \mathrm{~nm}$ dengan menggunakan spektrofotometer. Pengujian dilakukan dengan konsentrasi yang berbeda-beda, yaitu 0,78125 ppm, 1,5625 ppm, 3,125 ppm, 6,25 ppm, 12,5 ppm, 25 ppm, 50 ppm, 100 ppm, dan vitamin C sebagai kontrol positif (Maulida \& Naufal, 2014). Nilai \% hambatan dihitung dengan rumus:

$$
\% \text { Hambatan }=\frac{A_{\text {DPPH }(t)}-A_{\text {Sampel }(t)}}{A_{\text {DPPH }}(t)} \times 100 \% \ldots \ldots \ldots \ldots \ldots \ldots \ldots \ldots
$$

\section{Keterangan :}

1) $A_{D P P H(t)}$ adalah peyerapan dari DPPH dalam waktu $t$

2) $A_{\text {sampel(t) }}$ adalah penyerapan dari sampel dalam waktu

\section{Uji Aktivitas Antimikroba Pembuatan Media}

Media NA ditimbang sebanyak 28 gram dan glucose 10 gram, kemudian dilarutkan dengan aquades $1000 \mathrm{~mL}$ dalam Erlenmeyer, dipanaskan hingga mendidih dan tidak terdapat gumpalan. Diukur pH larutan menggunakan kertas pH meter Merk Universal, yaitu 6-7. Kemudian di autoclave pada suhu $121^{\circ} \mathrm{C}$ selama 15 menit. Larutan dituang ke dalam cawan petri yang steril dan ditutup lalu dibiarkan sampai memadat (Thohari et al., 2019).

\section{Pembenihan Bakteri}

Bakteri E. coli dan S. sobrinus ditanam dalam media Nutrient Broth (NB) sebanyak 10 $\mathrm{mL}$ dengan menggunakan satu ose, kemudian shaker media tersebut pada suhu ruangan selama 24 jam.

\section{Penanaman Pada Media NA (Nutrient Agar)}

Biakan bakteri $E$. coli dan S. sobrinus diambil sebanyak $100 \mu \mathrm{L}$, kemudian dituangkan ke dalam media NA yang telah memadat. Media NA dibiarkan selama 5 menit agar bakteri 
dapat meresap ke dalam agar. Kertas cakram yang berdiameter $5 \mathrm{~mm}$ direndam ke dalam masing-masing konsentrasi ekstrak akar segar bangle ( $Z$. montanum) selama 5 menit. Kemudian dimasukkan kertas cakram tersebut ke dalam cawan petri yang berisi media dan biakan bakteri dengan menggunakan pinset. Kertas cakram ditekan menggunakan pinset agar terjadi kontak yang baik antara kertas cakram dengan media NA. Kemudian diinkubasi selama 24 jam dengan suhu $37^{\circ} \mathrm{C}$ (Wuryanti et al., 2012). Diameter zona hambat dihitung dengan rumus:

Diameter zona hambat $=\frac{\left(D_{v}-D_{c}\right)+\left(D h-D_{c}\right)}{2}$ .5

Keterangan :

$\begin{array}{ll}\text { Dv } & \text { : Diameter vertical } \\ \text { Dh } & \text { : Diameter horizontal } \\ \text { Dc } & \text { : Diameter kertas cakram }\end{array}$

\section{Analisis Data}

Data yang diperoleh secara kualitatif dianalisis dengan menggunakan metode deskriptif dan uji metabolit sekunder dianalisis dengan menggunakan persamaan regresi linier berdasarkan perhitungan Total Phenolic Content (TPC), Total Flavonoid Content (TFC) dan aktivitas antioksidan.

\section{HASIL DAN PEMBAHASAN \\ Persen Rendemen}

Hasil analisis persen rendemen akar segar dari tanaman bangle ( $Z$. montanum) dapat dilihat pada Tabel 1.

Tabel 1.Hasil pengolahan dan ekstraksi akar segar bangle (Z. montanum)

\begin{tabular}{cccc}
\hline Sampel & Berat Simplisia $(\mathrm{g})$ & Berat Ekstrak $(\mathrm{g})$ & Bobot Rendemen (\%) \\
\hline Akar Segar & 417 & 3.42 & 0.82 \\
\hline
\end{tabular}

Rendemen ekstrak akar segar bangle sebesar $0.82 \%$ yang diperoleh dari 417 gram akar segar dan berat ekstrak sebesar 3.42 gram. Hasil yang terekstraksi dari rendemen simplisia akar segar bangle (tabel 1) dengan metode maserasi dapat menghasilkan senyawa metabolit sekunder yang akan digunakan dalam pengujian. Beberapa faktor yang mempengaruhi kualitas hasil rendemen simplisia yaitu umur tanaman, varietas tanaman, faktor lingkungan tanaman, proses panen dari tanaman tersebut, proses pemeliharaan tanaman dan proses pengolahan tanaman tersebut (Zuraida et al., 2017).

\section{Hasil Fitokimia}

Hasil uji fitokimia secara kualitatif dan terpenoid yang telah dilakukan dengan menggunakan ekstrak etanol akar segar bangle ( $Z$. montanum) menunjukkan bahwa terdapat kandungan senyawa metabolit sekunder seperti yang terlihat pada tabel 2 . 
Tabel 2.Uji fitokimia secara kualitatif

Metabolit Sekunder

Alkaloid
Flavonoid
Fenolik
Saponin
Triterpenoid
Steroid

Keterangan :

$(+)=$ Terdeteksi senyawa metabolit sekunder

$(-)=$ Tidak terdeteksi senyawa metabolit sekunder

Hasil pengujian secara kualitatif menunjukkan bahwa ekstrak etanol akar segar bangle ( $Z$. montanum) mengandung senyawa golongan alkaloid, flavonoid, fenolik, saponin dan triterpenoid. Menurut Sanatombi \& Sanatombi (2017) tanaman bangle memiliki kandungan senyawa aktif berupa flavonoid, fenolik, alkaloid. Ditambahkan oleh Padmasari et al., (2013) bahwa ekstrak etanol 70\% rimpang bangle mengandung saponin, flavonoid, minyak atsiri, alkaloid, tanin, dan glikosida.

\section{Nilai Total Fenolik dan Flavonoid}

Kandungan total fenolik dan flavonoid dari ekstrak etanol akar segar bangle ( $Z$. montanum) ditentukan berdasarkan metode kolorimetri dengan pereaksi follin-ciocalteu pada uji TPC dan pereaksi $\mathrm{AlCl}_{3}$ pada uji TFC. Kadar fenolik yang didapatkan dari kurva kalibrasi asam galat adalah nilai regresi linier yaitu $\mathrm{R}^{2}=0.9628$ dengan persamaan regresi linier adalah $y=0.0011 x+0.0451$. Hasil perhitungan nilai TPC sebesar $49.01 \mathrm{mg} \mathrm{GAE} / \mathrm{g}$. Kadar fenolik total yang diperoleh berkorelasi dengan kadar flavonoid total pada sampel. Kurva kalibrasi standar cathechin memiliki nilai regresi linier yaitu $\mathrm{R}^{2}=0.7778$ dengan persamaan regresi linier adalah $y=0.0002 x+0.0226$. Hasil kadar flavonoid total didapatkan sebesar $286.73 \mathrm{mg} \mathrm{CE} / \mathrm{g}$.

Nilai total flavonoid memiliki nilai tinggi dibandiungkan total fenolik, hal ini mungkin disebabkan molekul-molekul yang terdapat pada ekstrak akar segar bangle semakin banyak sehingga molekul yang akan menyerap cahaya pada panjang gelombang tertentu juga semakin banyak. Kadar flavonoid dan senyawa fenolik lain di dalam tanaman berbeda-beda di antara setiap bagian, jaringan dan umur tanaman serta dipengaruhi oleh faktor-faktor lingkungan. Faktor-faktor tersebut adalah temperatur, nutrisi, ketersediaan air dan kadar $\mathrm{CO}_{2}$ pada atmosfer (Gusnedi, 2013).

Kandungan total fenolik lebih rendah dibandingkan kandungan total flavonoid disebabkan oleh adanya senyawa fenolik yang mengalami kerusakan sebelum ekstraksi. Hal tersebut dapat terjadi karena proses pengeringan simplisia dilakukan dibawah sinar matahari secara langsung sehingga terjadinya kerusakan kandungan senyawa pada simplisia. Proses pengeringan mempengaruhi kandungan senyawa aktif yang ada di dalam simplisia. Kandungan fenolik dan flavonoid total berpengaruh terhadap aktivitas antioksidan. Senyawa antioksidan, fenolik dan flavonoid memiliki sifat yang sensitive terhadap panas dan cahaya (Egra et al., 2019).

\section{Antioksidan}

Hasil uji aktivitas antioksidan yang telah dilakukan dengan menggunakan ekstrak etanol akar segar tanaman bangle ( $Z$. montanum) menunjukkan bahwa ekstrak tersebut memiliki aktivitas antioksidan yang dapat dilihat pada Gambar 1. 


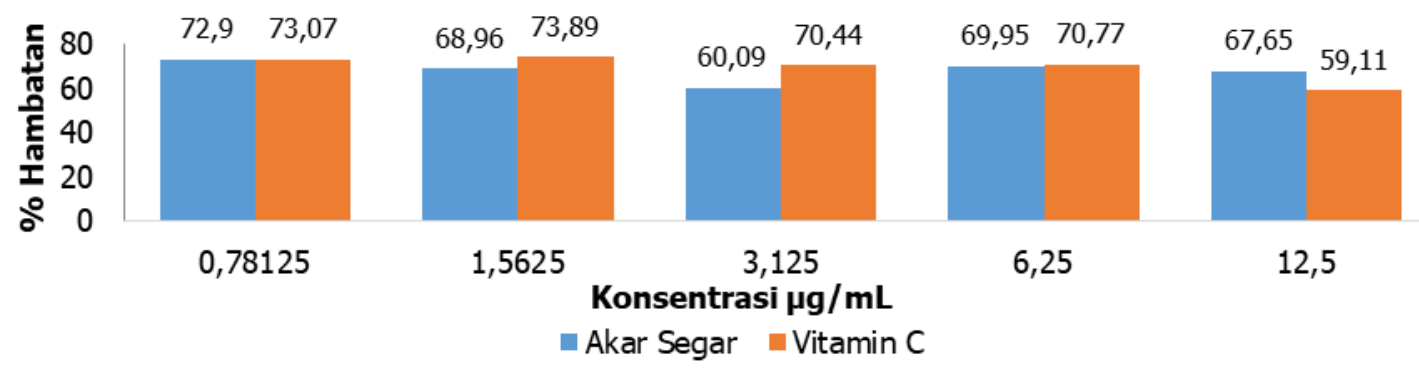

Gambar 1. \% Hambatan ekstrak akar segar dan Vitamin C

Metode yang digunakan dalam penelitian ini adalah metode DPPH karena efisiensi kinerja dari senyawa-senyawa antioksidan pada sampel dapat menetralisir radikal bebas. 1,1 - diphenyl-2-picrylhydrazyl (DPPH) adalah radikal bebas sintetik yang bersifat stabil terhadap suhu ruangan dan dapat larut dalam pelarut polar seperti etanol (Arsyad, 2014).

Hasil yang diperoleh menunjukkan bahwa ekstrak etanol akar segar bangle ( $Z$. montanum) memberikan penghambatan yang sangat kuat ditandai dengan nilai $\mathrm{IC}_{50}$ sebesar $0.993 \mu \mathrm{g} / \mathrm{mL}$ dan vitamin C sebagai pembanding memiliki nilai IC $_{50}$ sebesar $0.950 \mu \mathrm{g} / \mathrm{mL}$. Pengukuran vitamin $C$ dan sampel menggunakan panjang gelombang maksimum $514 \mathrm{~nm}$. Klasifikasi aktivitas antioksidan berdasarkan nilai $\mathrm{IC}_{50}(\mu \mathrm{g} / \mathrm{mL})$ yaitu sangat kuat jika nilai < $50 \mu \mathrm{g} / \mathrm{mL}$, kuat jika nilai $50-100 \mu \mathrm{g} / \mathrm{mL}$, sedang jika nilai $100-150 \mu \mathrm{g} / \mathrm{mL}$ dan lemah jika nilai $150-200 \mu \mathrm{g} / \mathrm{mL}$ (Kiromah et al., 2021).

Berdasarkan Klasifikasi Nilai IC 50 aktivitas antioksidan yang dimiliki oleh ekstrak etanol akar segar bangle ( $Z$. montanum) dapat dikategorikan sebagai antioksidan sangat kuat karena nilai $\mathrm{IC}_{50}$ yang didapatkan lebih kecil dari $50 \mu \mathrm{g} / \mathrm{mL}$. Hal ini sesuai dengan hasil yang diperoleh dari penelitian (Kantayos \& Paisooksantivatana, 2012) bahwa aktivitas antioksidan pada rimpang bangle ( $Z$. montanum) memiliki nilai $\mathrm{IC}_{50}$ sebesar $4.71 \mu \mathrm{g} / \mathrm{mL}$. Hasil yang didapatkan dipengaruhi oleh beberapa faktor seperti penggunaan metode, prosedur ekstraksi dan pelarut yang digunakan dalam pengujian.

Flavonoid dan fenolik merupakan senyawa metabolit sekunder yang terdapat pada tumbuhan dan memiliki peran sebagai aktivitas antioksidan. Apabila kandungan senyawa fenol lebih banyak maka aktivitas antioksidan semakin besar. Struktur fenolik berkontribusi terhadap aktivitas antioksidan yang mempengaruhi jumlah lokasi gugus $-\mathrm{OH}$ sehingga dapat menetralkan radikal bebas. Senyawa golongan fenol memiliki efek biologis terhadap aktivitas antioksidan dengan mekanisme penghelat logam, pereduksi, pendonor elektron dan penangkap radikal bebas (Nur et al., 2019).

\section{Nilai Aktivitas Antibakteri}

Hasil penelitian menunjukkan bahwa ekstrak etanol akar segar bangle ( $Z$. montanum) terhadap bakteri Escherichia coli dan Streptococcus sobrinus memiliki daya hambat antibakteri dari konsentrasi yang berbeda, dapat dilihat pada gambar 2, sebagai berikut.

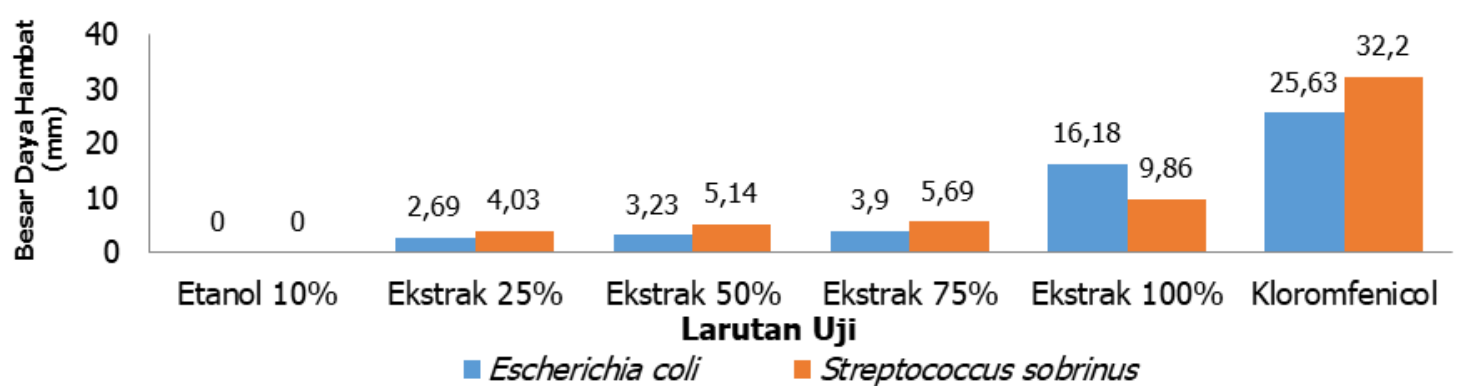

Gambar 2. Kurva antibakteri 
Penelitian uji aktivitas antibakteri menggunakan ekstrak etanol akar segar bangle ( $Z$. montanum) pada konsentrasi 25\%, 50\%, 75\% dan 100\% terhadap bakteri Escherichia coli dan Streptococcus sobrinus. Efektivitas antibakteri dapat dilihat (Gambar 3) dengan terbentuknya zona hambat (bening) disekitar kertas cakram. Ekstrak akar segar bangle (Zingiber montanum) memiliki aktivitas antibakteri berdasarkan klasifikasi menurut Fitriani (2020) yaitu aktivitas anti bakteri lemah pada konsentrasi $25 \%, 50 \%$ dan $75 \%$ pada bakteri Escherichia coli dengan rata-rata zona hambat $<5 \mathrm{~mm}$, sedangkan pada konsentrasi $100 \%$ ekstrak akar segar bangle memiliki aktivitas antibakteri kuat dengan rata-rata zona hambat 10-20 mm. Pada bakteri Streptococcus sobrinus memiliki aktivitas antibakteri lemah pada konsentrasi $25 \%$ dengan rata-rata zona hambat $<5 \mathrm{~mm}$, pada konsentrasi $50 \%$, $75 \%$ dan $100 \%$ termasuk kedalam aktivitas antibakteri sedang dengan rata-rata zona hambat 5-10 $\mathrm{mm}$. Menurut Marliani (2014) ekstrak rimpang bangle ( $Z$. cassumunar Roxb.) memiliki daya hambat terhadap bakteri gram negatif maupun gram positif.

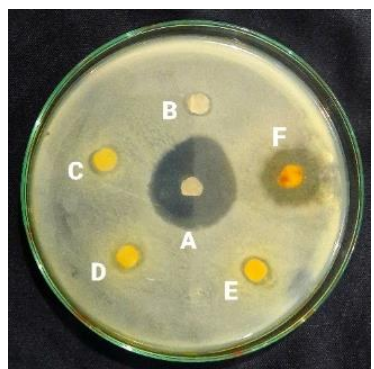

Escherichia coli

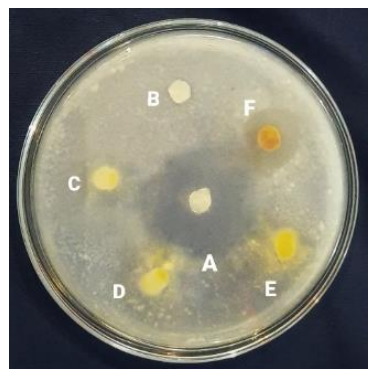

Streptococcus sobrinus

Gambar 3. Hasil Aktivitas Antibakteri pada Bakteri Escherichia coli dan Streptococcus sobrinus. A. Kloromfenikol sebagai kontrol positif; B. Etanol 10\% sebagai kontrol negatif; C. Larutan ekstrak 25\%; D. Larutan ekstrak 50\%; E. Larutan ekstrak 75\%; F. Larutan ekstrak 100\%.

Penggunaan Nutrient Broth (NB) dan Nutrient Agar (NA) pada penelitian ini sebagai media universal untuk dilakukan kultur pembiakan bakteri karena mengandung nutrisi yang cukup untuk pertumbuhan bakteri. Penggunaan kloromfenicol sebagai kontrol positif karena termasuk kedalam golongan antibiotik yang mempunyai aktivitas bakteriostatik dan memiliki spektrum luas pada diameter zona hambat yang terbentuk terhadap bakteri gram negatif maupun bakteri gram positif (Kantayos \& Paisooksantivatana, 2012). Kontrol negatif yang digunakan adalah etanol $10 \%$. Ekstrak akar segar bangle (Z. montanum) menunjukkan adanya efek bakteriostatik terhadap kedua bakteri. Ekstrak akar segar bangle dapat menghambat pertumbuhan bakteri $E$. coli dan $S$. sobrinus disebabkan oleh adanya senyawa bioaktif yang memiliki efektivitas antibakteri yang terkandung di dalam akar segar bangle ( $Z$. montanum). Senyawa bioaktif tersebut adalah flavonoid, alkaloid dan saponin. Senyawa bioaktif dari ekstrak akar segar bangle berbeda tiap konsentrasi. Semakin tinggi konsentrasi maka efek bakteriostatiknya semakin besar.

Penghambatan pertumbuhan bakteri dapat disebabkan oleh adanya kerusakan yang terjadi pada komponen struktural membran sel bakteri. Menurut Ernawati \& Hasmila (2015) struktur membran sel tersusun dari lipid dan protein. Kerusakan membran sel disebabkan oleh kandungan senyawa bioaktif yang dapat menurunkan pertumbuhan koloni bakteri dan dapat mengalami gangguan transport nutrisi (senyawa dan ion) dari membran sel sehingga pertumbuhan sel bakteri mengalami kekurangan nutrisi.

\section{Kesimpulan}

Ekstrak akar segar bangle mengandung senyawa fitokimia berupa alkaloid, fenolik, flavonoid, saponin dan triterpenoid serta nilai TPC, TFC, dan antioksidan adalah $49.01 \mathrm{mg}$ $\mathrm{GAE} / \mathrm{g}$, $394.07 \mathrm{mg} \mathrm{CE} / \mathrm{g}$ dan $0.993 \mu \mathrm{g} / \mathrm{mL}$. Aktivitas antioksidan ekstrak akar segar tanaman 
bangle tergolong yang sangat kuat. Aktivitas antibakteri memiliki daya hambat pada bakteri Escherichia coli dan Streptococcus sobrinus dengan konsentrasi 100\% secara berturut-turut adalah $16.18 \mathrm{~mm}$ (kategori kuat) dan $9.86 \mathrm{~mm}$ (kategori sedang).

\section{Daftar Pustaka}

Alfian, R. \& Susanti, H. (2012). Penetapan Kadar Fenolik Total Ekstrak Metanol Kelopak Bunga Rosella Merah (Hibiscus sabdariffa Linn) Dengan Variasi Tempat Tumbuh Secara Spektrofotometri. Pharmaciana, 2(1), pp. 73-80. doi: 10.12928/pharmaciana.v2i1.655.

Arsyad, A. B. (2014). Analisis Pengaruh Waktu Pemanasan Terhadap Degradasi Aktivitas Antioksidan Pada Daun Kangkung Air (Ipomoea aquatica Forsk). Institut Agama Islam Negeri Walisongo Semarang.

Arung, E. T., Shimizu, K. \& Kondo, R. (2006). Inhibitory effect of artocarpanone from Artocarpus heterophyllus on melanin biosynthesis. Biological and Pharmaceutical Bulletin, 29(9), pp. 1966-1969. doi: 10.1248/bpb.29.1966.

Aunjum, A., Biswas, R., Nurunnabi, T., Rahman, S. M. M., Billah, Md M., Islam, Md E. \& Islam, K. M. D. (2019). Antioxidant and antibacterial activity of three herbs belonging to Zingiber genus of Bangladesh. Oriental Pharmacy and Experimental Medicine. doi: 10.1007/s13596-019-00403-y.

Batubara, I., Trimulia, R., Rohaeti, E. \& Darusman, L. K. (2018). Hubungan Lama Distilasi, Kandungan Senyawa, dan Bioautografi Antioksidan Minyak Atsiri Bangle (Zingiber purpureum). Indonesian Journal Of Essential Oilx, No.x, 3(1), pp. 37-44.

Citradewi, A., Sumarya, I. M.\& Juliasih, N. K. A. (2019). Daya Hambat Ekstrak Rimpang Bangle (Zingiber purpureum Roxb.) Terhadap Pertumbuhan BakteriStaphylococcus aureus. Jurnal Widya Biologi, 10(01), pp. 45-53. doi: 10.32795/widyabiologi.v10i01.236.

Egra, S., Mardhiana., Patriawan, R., Kartina., Sirait, S. \& Kuspradini, H. (2019). Aktivitas Antimikroba Tanaman Paku (Stenochlaena palustris dan Pteridium caudatum) Terhadap Bakteri (Ralstonia solanacearum dan Streptococcus sobrinus). Jurnal Jamu Indonesia, 4(1), pp. 28-36. doi: 10.29244/jji.v4i1.93.

Egra, S., Mardiana., Kurnia, A., Kartina., Murtilaksono, A. \& Kuspradini, H. (2019). Uji Potensi Ekstrak Daun Tanaman Ketepeng (Cassia alata L) Dalam Menghambat Pertumbuhan Bakteri Ralstonia solanacearum dan Streptococcus sobrinus. Hut Trop, 3(1), pp. 1183. doi: 10.13057/biodiv/d1601xx.

Ernawati \& Hasmila, I. (2015). Uji Fitokimia dan Aktifitas Antibakteri Senyawa Metabolit Sekunder Ekstrak Metanol Daun Mangrove (Rhizophora mucronata). Jurnal Bionature, 16(2), pp. 98-102.

Febrina, L., Rusli, R. \& Muflihah, F. (2015). Optimalisasi Ekstraksi dan Uji Metabolit Sekunder Tumbuhan Libo. Journal of Tropical Pharmacy Chemistry, 3(2), pp. 74-81.

Fitriani, N. H. (2020). Efek Antimikroba Ekstrak Daun Pepaya (Carica papaya L.) Terhadap Pertumbuhan Propionibacterium acnes Secara In Vitro. Skripsi, Universitas Muhammadiyah Malang. Available at: https://eprints.umm.ac.id/58468/.

Gusnedi, R. (2013). Analisis Nilai Absorbansi dalam Penentuan Kadar Flavonoid untuk Berbagai Jenis Daun Tanaman Obat. Pillar of Physics, 2, pp. 76-83.

Kantayos, V. \& Paisooksantivatana, Y. (2012). Antioxidant Activity and Selected Chemical Components of 10 Zingiber spp. in Thailand. Journal of Developments in Sustainable Agriculture, 7(1), pp. 89-96. doi: 10.11178/jdsa.7.89.

Kapitan, O. B., Ambarsari, L. \& Falah, S. (2017). In Vitro Antibakteri Ekstrak Etanol Puni (Zingiber zerumbet) Asal Pulau Timor. Savana Cendana, 2(02), pp. 29-32. doi: $10.32938 / \mathrm{sc} . \mathrm{V} 2 \mathrm{i} 02.82$.

Kiromah, N. Z. W, Fitriyati, L \& Husein, S. (2021). Uji Aktivitas Antioksidan Ekstrak Metanol 
Dan Akuades Daun Ganitri (Elaeocarpus ganitrus Roxb.) Dengan Metode Dpph (2,2Difenil-1-Pikrihidrazi). pp. 79-85.

Maizura, M. (2011). Total phenolic content and antioxidant activity of kesum (Polygonum minus), ginger (Zingiber officinale) and turmeric (Curcuma longa) extract. International Food Research Journal, 18(9), pp. 529-534.

Marliani, L. I. (2014). Aktivitas Antibakteri dan Telaah Senyawa Komponen Minyak Atsiri Rimpang Bangle (Zingiber cassumunar Roxb.). Prosiding Seminar Nasional Penelitian dan PKM, 3(1), pp. 1-6.

Maulida, D. \& Naufal, L. C. (2010). Ekstraksi Antioksidan (Likopen) Dari Buah Tomat Dengan Menggunakan Solven Campuran, N-Heksana, Aseton, Dan Etanol. Skripsi, Universitas Diponegoro.

Nur, S., Sami, F. J., Wilda, R., Awaluddin, A. \& Afsari, M. I. A. (2019). Korelasi Antara Kadar Total Flavonoid dan Fenolik dari Ekstrak dan Fraksi Daun Jati Putih (Gmelina Arborea Roxb.) Terhadap Aktivitas Antioksidan. Jurnal Farmasi Galenika, 5(1), pp. 33-42. doi: 10.22487/j24428744.2019.v5.i1.12034.

Nurkhasanah, Santoso, R. D. \& Fauziah, R. (2017). The immunomodulatory effect of Zingiber cassumunar ethanolic extract on phagocytic activity, nitrit oxide and reaxtive oxygen intermediate secretions of macrophage in mice. in IOP Conference Series: Materials Science and Engineering. Institute of Physics Publishing, pp. 1-7. doi: 10.1088/1757899X/259/1/012007.

Padmasari, P. D., Astuti, K. W. and Warditiani, N. K. (2013). Skrining Fitokimia Ekstrak Etanol 70\% Rimpang Bangle (Zingiber purpureum Roxb.). Farmasi Udayana, (2(4)), pp. 1-7.

Prasetya, Y. A. Winarsih, I. Y., Pratiwi, K. A, Hartono, M. C. \& Rochimah, D. N. (2019). Deteksi Fenotipik Escherichia coli Penghasil Extended Spectrum Beta-lactamases (ESBLs) pada Sampel Makanan di Krian Sidoarjo. Life Science, 8(1), pp. 95-105. doi: 10.15294/lifesci.v8i1.29995.

Rahayu, W. P. (2018) Escherichia coli: Patogenitas, Analisis dan Kajian Risiko. Bogor: Press., IPB.

Available

at:https://books.google.co.id/books?hl=id\&lr=\&id=jNcrEAAAQBAJ\&oi=fnd\&pg=PP1\&d

$\mathrm{q}=$ Rahayu,+ W.+P.+(2018).+Escherichia+coli+:+Patogenitas, +Analisis+dan+Kajian+R isiko.+Bogor:+IPB+Press.\&ots=7GxSyXks40\&sig=ZENzhIPqpwOljmwZwPINGIYJpRE\&re dir_esc $=y \# v=$ onepage $\& q \& f=$ false.

Riasari, H., Rachmaniar, R. \& Wahyuni, S. (2019). Evaluation Patch of Rhizoma Extract Kencur (Kaempferia galanga L.) as Anti-Inflammatory with Enhancer. Indonesian Journal of Pharmaceutical Science and Technology, 6(2), pp. 59. doi: 10.24198/ijpst.v6i2.18932.

Rungruang, R., Ratanathavorn, W., Boohuad, N., Selamassakul, O. \& Kaisangsri, N. (2021). Antioxidant and anti-aging enzyme activities of bioactive compounds isolated from selected Zingiberaceae plants. Agriculture and Natural Resources, 55(1), pp. 153-160. doi: 10.34044/j.anres.2021.55.1.20.

Sanatombi, R. \& Sanatombi, K. (2017). Biotechnology of Zingiber montanum (Koenig) Link ex A. Dietr.: A review. Journal of Applied Research on Medicinal and Aromatic Plants, 4, pp. 1-4. doi: 10.1016/j.jarmap.2016.09.001.

Santoni, A. (2019). Identifikasi Senyawa Metabolit Sekunder, Uji Antimikroba dan Antioksidan Ekstrak Akar Gantung Hornstedtia Scyphifera Var. Fusiformis Holttum (Sijangkang). Jurnal Riset Kimia, 10(2), pp. 98-102. doi: 10.25077/jrk.v10i2.264.

Thohari, N. M., Pestariati \& Istanto, W. (2019). Pemanfaatan Tepung Kacang Hijau (Vigna radiata L.) Sebagai Media Alternatif NA (Nutrient Agar) Untuk Pertumbuhan Bakteri Escherichia coli. Jurnal analisis Kesehatan Klinikal Sains, 8(2), pp. 725-737. Available at: journal.poltekkesdepkes-sby.ac.id. 
Wachidah, L. N. (2013). Uji Aktivitas Antioksidan Serta Penentuan Kandungan Fenolat Dan Flavonoid Total Dari Buah Parijoto (Medinilla speciosa Blume). Skripsi, Universitas Islam Negeri Syarif Hidayatullah Jakarta.

Wijaya, H., Novitasari \& Jubaidah, S. (2018). Perbandingan Metode Ekstraksi Terhadap Rendemen Ekstrak Daun Rambui Laut (Sonneratia caseolaris L. Engl). Jurnal Ilmiah Manuntung, 4(1), pp. 79-83.

Wuryanti., Mulyani, N. S., Asy'ari, M. \& Sarjono, P. R. (2012). Uji Ekstrak Bawang Bombay sebagai Anti Bakteri Gram Positif Staphylococcus aureus dengan Metode Difusi Cakram. Bioma: Berkala I/miah Biologi, 12(2), pp. 69-73. doi: 10.14710/bioma.12.2.68-72.

Zou, Y., Lu, Y. \& Wei, D. (2004). Antioxidant activity of a flavonoid-rich extract of Hypericum perforatum L. in vitro. Journal of Agricultural and Food Chemistry, 52(16), pp. 50325039. doi: 10.1021/jf049571r.

Zuraida., Sulistiyani., Sajuthi, D. \& Suparto, I. H. (2017). Fenol, Flavonoid, Dan Aktivitas Antioksidan Pada Ekstrak Kulit Batang Pulai (Alstonia scholaris R.Br). Jurnal Penelitian Hasil Hutan, 35(3), pp. 211-219. doi: 10.20886/jphh.2017.35.3.211-219. 